(2) Open Access Full Text Article

\title{
Arsenic sulfide combined with JQI, chemotherapy agents, or celecoxib inhibit gastric and colon cancer cell growth
}

This article was published in the following Dove Press journal:

Drug Design, Development and Therapy

30 October 2015

Number of times this article has been viewed

\author{
Lian Zhang' \\ Yingying Tong' \\ Xiuli Zhang' \\ Minggui Pan ${ }^{2,3}$ \\ Siyu Chen'
}

'Department of Oncology, Xin Hua Hospital Affiliated to Shanghai Jiao Tong University School of Medicine, Shanghai, People's Republic of China; ${ }^{2}$ Department of Oncology and Hematology, Kaiser Permanente Medical Center, Santa Clara, ${ }^{3}$ Division of Research, Kaiser Permanente, Oakland, CA, USA
Correspondence: Siyu Chen Department of Oncology, Xin Hua Hospital Affiliated to Shanghai Jiao Tong University School of Medicine, I 665 Kongjiang Road, Shanghai 200092, People's Republic of China Tel +86 2l 25077642

Email siyu.chen@shsmu.edu.cn

Minggui Pan

Department of Oncology and Hematology, Kaiser Permanente Medical Center, 710 Lawrence Expressway, Santa Clara, CA 9505I, USA

$\mathrm{Tel}+\mathrm{I} 408$ 85। 4306

Email minggui.pan@kp.org
Background: Arsenic compounds have modest cytotoxic activity in solid tumors. We investigated if arsenic sulfide $\left(\mathrm{As}_{4} \mathrm{~S}_{4}\right)$ in combination with other distinct agents could enhance its cytotoxic activity.

Methods: We used gastric and colon cancer cell lines to study the synergistic effect of $\mathrm{As}_{4} \mathrm{~S}_{4}$ in combination with BRD4 inhibitor JQ1, or with chemotherapy drug cisplatin and irinotecan or with COX2 inhibitor celecoxib. We investigated the mechanism of the cytotoxic effect of these novel combinations.

Results: We found that when $\mathrm{As}_{4} \mathrm{~S}_{4}$ was combined with JQ1, cisplatin, irinotecan or celecoxib, its cytotoxic activity was dramatically enhanced in both gastric and colon cancer cell lines. $\mathrm{As}_{4} \mathrm{~S}_{4}$ and JQ1 inhibited BRD4 and c-Myc while activating p53 expression synergistically. $\mathrm{As}_{4} \mathrm{~S}_{4}$ inhibited COX2 and cyclin D1 expression. When $\mathrm{As}_{4} \mathrm{~S}_{4}$ was combined with chemotherapy drug cisplatin or COX2 inhibitor celecoxib, its inhibition of COX2, BCL2, and p38 expression was enhanced. $\mathrm{As}_{4} \mathrm{~S}_{4}$ and cisplatin synergistically stimulated p53, phosphor-p38 (p-p38), and increased cleaved caspase 3 (c-caspase 3).

Conclusion: $\mathrm{As}_{4} \mathrm{~S}_{4}$ in combination with JQ1, cisplatin, irinotecan or celecoxib showed enhanced cytotoxic effect on gastric and colon cancer cells, indicating the potential application of these novel drug combinations as part of treatment strategy that warrants further investigation. $\mathrm{As}_{4} \mathrm{~S}_{4}$ and JQ1 demonstrate synergistic activation of p53 and inhibition of c-Myc. $\mathrm{As}_{4} \mathrm{~S}_{4}$ and cisplatin and celecoxib activated multiple apoptosis pathways.

Keywords: $\mathrm{As}_{4} \mathrm{~S}_{4}$, JQ1, cisplatin, irinotecan, celecoxib, gastric cancer, colon cancer

\section{Introduction}

Arsenic compounds are important drugs that have been used in both People's Republic of China and the Western world for more than 2,000 years. Arsenic trioxide $\left(\mathrm{As}_{2} \mathrm{O}_{3}\right)$ and arsenic sulfide $\left(\mathrm{As}_{4} \mathrm{~S}_{4}\right)$ were discovered to have excellent anti-leukemic activity especially against acute promyelocytic leukemia (APL). ${ }^{1-5} \mathrm{As}_{2} \mathrm{O}_{3}$ has a synergistic effect when combined with all-trans-retinoic acid (ATRA). The exact mechanism of such synergistic effect on APL remains incompletely understood, though it was discovered that their combined effect on inducing the degradation of promyelocytic leukemia protein most likely mediates the induction of cell differentiation and apoptosis. ${ }^{6,7}$ In chronic myelocytic leukemia, $\mathrm{As}_{4} \mathrm{~S}_{4}$ seems to use a different mechanism by activating c-CBL, preventing its self-ubiquitination, therefore increasing its protein degradation activity against several oncogene products including some receptor tyrosine kinases. ${ }^{8}$

In our previous studies, we explored the anticancer effect and mechanism of $\mathrm{As}_{4} \mathrm{~S}_{4}$ on a series of solid tumor cell lines, and showed that $\mathrm{As}_{4} \mathrm{~S}_{4}$ possessed potent antitumor activities in solid tumors by inducing apoptosis..$^{9}{ }^{10}$ Meanwhile, we carried 
out further studies with gastric cancer cells and showed that the mechanism of $\mathrm{As}_{4} \mathrm{~S}_{4}$ induced apoptosis both in vitro and in vivo was associated with p53-dependent pathway. ${ }^{11}$ The potent anti-APL effect of $\mathrm{As}_{2} \mathrm{O}_{3}$ and ATRA combination led us to ask if $\mathrm{As}_{4} \mathrm{~S}_{4}$ could exert enhanced cytotoxic effect on solid tumor cells when combined with other distinct agents. We also sought to understand the mechanism of arsenic's cytotoxic activity in solid tumor cells through studying its interaction with other agents.

JQ1 is an inhibitor of epigenetic modifier protein BRD4. BRD4 is a member of the classic BET family which contains BRD2, BRD3, and BRDT. ${ }^{12-14}$ BRD4 is a transcriptional regulator that recruits transcriptional regulatory complex to the acetylated chromatin to control the expression of an array of proteins including c-Myc. ${ }^{15}$ JQ1 was found to be a potent BRD4 inhibitor and has been shown to have excellent inhibitory activity in myeloma and acute myeloid leukemia cells. ${ }^{16,17}$ It potently inhibits c-Myc expression. ${ }^{15}$

Cisplatin and irinotecan are important chemotherapy agents that have broad cytotoxic activity in many malignancies including testicular cancer, lung cancer, ovarian cancer, head and neck cancer, gastric and colorectal cancer, etc. ${ }^{18}$ Cisplatin interacts with DNA to form DNA adducts therefore blocking DNA replication and causing apoptosis. ${ }^{15}$ It activates p53 as well as many other tumor suppressor genes. ${ }^{18}$ Irinotecan is a topoisomerase I inhibitor that is particularly active for colorectal cancer and is often used as first or second line alone or in combination with 5-fluorouracil. ${ }^{19}$

Celecoxib is a COX2 inhibitor and has been shown to prevent colorectal polyps. ${ }^{20-22}$ It potently inhibits COX2 enzymatic activity and reduces the level of inflammatory prostaglandin. ${ }^{17-19}$ It can inhibit the cell growth of colorectal, gastric, and liver cancer cells and has been shown in clinical trials to decrease the size and the numbers of polyps in patients with familiar adenomatous polyposis. ${ }^{23-26}$ It also has inhibitory activity in several other cancer cell types. ${ }^{27,28}$

In this study we aimed to investigate the synergistic effect of $\mathrm{As}_{4} \mathrm{~S}_{4}$ with JQ1, cisplatin, irinotecan, and celecoxib, four very distinct agents that have unique molecular mechanisms and regulate diverse signaling pathways. We chose JQ1 because of its promising anticancer property and novel mechanism. We chose cisplatin, irinotecan, and celecoxib because of their well-established clinical utility in gastrointestinal malignancies. We found that $\mathrm{As}_{4} \mathrm{~S}_{4}$ exerts synergistic or enhanced cytotoxic activity in gastric and colon cancer cell lines when combined with JQ1, cisplatin, irinotecan as well as celecoxib. In addition, $\mathrm{As}_{4} \mathrm{~S}_{4}$ uses a distinct mechanism to carry out its activity by regulating multiple apoptotic signaling pathways including p53, c-Myc, BAX, and p38 pathways, in a synergistic manner with the four agents. $\mathrm{As}_{4} \mathrm{~S}_{4}$ and JQ1 synergistically activate the expression of $\mathrm{p} 53$ and inhibit c-Myc. These novel combinations of the drugs with distinct mechanisms may have potential for clinical applications in the future and warrant further studies.

\section{Materials and methods}

\section{Cell lines, chemical agents}

The human gastric cancer AGS (harboring wild-type p53), MGC803 (harboring mutant-type p53), human colon cancer HCT116 (harboring wild-type p53), and SW480 (harboring mutant-type p53) cell lines were purchased from the Cell Bank of the Type Culture Collection of the Chinese Academy of Sciences (Institute of Biochemistry and Cell Biology, Shanghai Institutes for Biological Sciences, Chinese Academy of Sciences, Shanghai, People's Republic of China). No ethics statement was required from the institutional review board for the use of these cell lines. AGS cells were cultured in Dulbecco's Modified Eagle's Medium/F-12 1:1 (Hyclone, Logan, UT, USA), MGC803 cells were cultured in Roswell Park Memorial Institute 1640 medium (Thermo Fisher Scientific, Waltham, MA, USA), and SW480 and HCT116 cells were cultured in Dulbecco's Modified Eagle's Medium at $37^{\circ} \mathrm{C}$ and $5 \%$ $\mathrm{CO}_{2}$, supplemented with $10 \%$ fetal bovine serum (Thermo Fisher Scientific). Highly purified realgar which is the natural mineral form of $\mathrm{As}_{4} \mathrm{~S}_{4}$ was supplied by the Shanghai Institute of Hematology (Shanghai, People's Republic of China), and was dissolved in Dulbecco's phosphate-buffered saline (DPBS) (Thermo Fisher Scientific), sterilized by filtration. The concentration of $\mathrm{As}_{4} \mathrm{~S}_{4}$ stock solution was 277.2496 $\mu \mathrm{M}$ after the test of inductively coupled plasma atomic emission spectrometry. Then, the stock solution was stored at $4{ }^{\circ} \mathrm{C}$ and diluted to the appropriate concentration by DPBS to obtain a working solution. The concrete methods about preparation and purity analysis of $\mathrm{As}_{4} \mathrm{~S}_{4}$ were performed as previously described. ${ }^{11} \mathrm{JQ} 1$ was purchased from BPS bioscience (San Diego, CA, USA). Cisplatin, manufactured by Hansoh Pharmaceutical (Lianyungang, Jiangsu, People's Republic of China), and irinotecan, manufactured by Pfizer, Inc. (New York, NY, USA) were obtained from Xin Hua Hospital Affiliated to Shanghai Jiao Tong University School of Medicine (Shanghai, People's Republic of China). Celecoxib was purchased from Selleck Chemicals (Houston, TX, USA). The compounds of cisplatin and irinotecan were dissolved in normal saline, and the compounds of JQ1 and celecoxib were dissolved in dimethyl sulfoxide (SigmaAldrich Co., St Louis, MO, USA). The anti-Bcl-2, anti-Bax, anti-c-Myc, anti-p38, anti-phosphor-p38, and anti-cleaved 
caspase 3 antibodies were purchased from Cell Signaling Technology (Beverly, MA, USA), anti-BRD4 and anticyclin D1 from Abcam (Cambridge, MA, USA), anti-COX2 and anti- $\beta$-actin antibody from Proteintech Group, Inc (Wuhan, Hubei, People's Republic of China). Anti-p53, 3-(4,5-dimethylthiazol-2-yl)-2,5-diphenyltetrazolium bromide (MTT), and sodium dodecyl sulfate (SDS) powder were purchased from Sigma-Aldrich Co.

\section{Cell viability assay}

The effect of $\mathrm{As}_{4} \mathrm{~S}_{4}$ combined with JQ1, cisplatin, irinotecan, and celecoxib on gastric and colon cancer cell proliferation was assessed using MTT assay. The MTT assay was performed as previously described. ${ }^{10}$ AGS, MGC803, HCT116, and SW480 cells were seeded in 96-well plates at a density of $5 \times 10^{3}$ cells/well and incubated overnight. On the following day, cells were incubated with different concentrations of reagents for 24 or 48 hours, respectively. In our previous study, we found that the moderate dose of $\mathrm{As}_{4} \mathrm{~S}_{4}$ is $1.0-1.5 \mu \mathrm{M}$ for AGS and MGC803 cells. ${ }^{11}$ And the halfmaximal inhibitory concentration $\left(\mathrm{IC}_{50}\right)$ values of HCT116 cells when treated with $\mathrm{As}_{4} \mathrm{~S}_{4}$ for 24 hours was $12.13 \mu \mathrm{M}$. The concentration of JQ1, cisplatin, irinotecan, and celecoxib were determined according to the results of our preliminary experiment which was conducted by referencing the existing literature. ${ }^{29-33}$ Subsequently, $10 \mu \mathrm{L}$ MTT solution $(5 \mathrm{mg} / \mathrm{mL})$ was added to each well and incubated for 4 hours at $37^{\circ} \mathrm{C}$. After that, $150 \mu \mathrm{L}$ SDS solution (10\% concentration) was added to each well to dissolve the formazan at $37^{\circ} \mathrm{C}$ overnight. The proliferation-inhibitory effects of each combination were assessed using a microplate reader (Bio-TEK, Winooski, VT, USA) at $562 \mathrm{~nm}$. Data were analyzed based on three independent experiments and the relative cell viability was expressed as the percentage of untreated well.

\section{Western blotting analysis}

Western blotting analysis was performed as previously described. ${ }^{11}$ After drug treatment for 24 hours, cells were washed with PBS buffer and lysed in radioimmunoprecipitation assay Lysis Buffer (Beyotime, Shanghai, People's Republic of China) containing 1\% dilution of the phenylmethanesulfonyl fluoride (Beyotime) on ice. Protein concentration was determined by bicinchoninic acid protein assay kit (Beyotime) according to the manufacturer's protocol. Equal amounts of protein samples $(30-50 \mu \mathrm{g})$ were separated by $8 \%$ SDS-polyacrylamide gel electrophoresis and transferred onto a polyvinylidene fluoride membrane (Merck Millipore, Billerica, MA, USA). After blocking in 5\% non-fat milk, the membranes were incubated with the specific primary antibodies at $4^{\circ} \mathrm{C}$ overnight. Then, the membranes were incubated with horseradish peroxidase labeled goat anti-mouse or anti-rabbit secondary antibody at room temperature for 1 hour. Finally, proteins were detected with an Immobilon Western Chemilum HRP Substrate kit (Millipore) and were semi-quantified by Image Lab software (version 3.0; Bio-Rad Laboratories, Inc., Hercules, CA, USA). $\beta$-actin was used as a control for equal loading of samples.

\section{Statistical analysis}

Statistical analysis was performed using SPSS software version 19.0 (IBM Corporation, Armonk, NY, USA). All data were presented as the mean \pm standard deviation. Data analysis was performed using one-way analysis of variance, followed by either the least significant difference procedure (if variance was equal) or the Games-Howell procedure (if variance was unequal). Tukey's post hoc test was used for multiple group comparisons and Student's $t$-test was used for single comparisons. A twosided $P<0.05$ was considered statistically significant.

\section{Results JQI enhanced the cytotoxic effect of $\mathrm{As}_{4} \mathrm{~S}_{4}$ in gastric and colon cancer cells}

Because $\mathrm{As}_{4} \mathrm{~S}_{4}$ alone has modest activity against solid tumors we sought to identify agents that can enhance $\mathrm{As}_{4} \mathrm{~S}_{4}$ 's cytotoxicity and increase its efficacy. JQ1 is an experimental drug that has shown excellent activities against multiple myeloma cells and acute myeloid leukemia cells in pre-clinical studies, ${ }^{15-17}$ however, there are little data on its activity in solid tumors. We first tested whether $\mathrm{As}_{4} \mathrm{~S}_{4}$ and JQ1 have an enhanced effect on the cell killing in gastric and colon cancer cells. As shown in Figure 1A, using AGS gastric cancer cell line, $\mathrm{As}_{4} \mathrm{~S}_{4}$ at $1.5 \mu \mathrm{M}$ caused approximately $63 \%$ reduction of cell growth compared to the untreated control after 48 hours, while JQ1 at $1.0 \mu \mathrm{M}$ caused $40 \%$ reduction, indicating both agents have modest cytotoxic activity against AGS cells. JQ1 at $10 \mu \mathrm{M}$ did not seem to increase cell killing compared to $1.0 \mu \mathrm{M}$ and even at $20 \mu \mathrm{M}$ the cell killing effect was not significantly increased, indicating JQ1 at $1.0 \mu \mathrm{M}$ showed maximum cell growth inhibition in AGS cells. When $\mathrm{As}_{4} \mathrm{~S}_{4}$ was combined with JQ1 in $1.0,10$ or $20 \mu \mathrm{M}$, a synergistic effect on cell killing was observed, with more than $80 \%$ inhibition of cell growth, indicating $\mathrm{As}_{4} \mathrm{~S}_{4}$ and JQ1 may be an effective combination in gastric cancer cells. We next examined a different gastric cancer cell line, MGC803. As shown in Figure $1 \mathrm{~B}, \mathrm{As}_{4} \mathrm{~S}_{4}$ at $1.0 \mu \mathrm{M}$ caused approximately $40 \%$ inhibition of cell growth in 48 hours while JQ1 showed approximately $45 \%$ inhibition. The combination of these two agents together showed approximately $60 \%$ inhibition, 

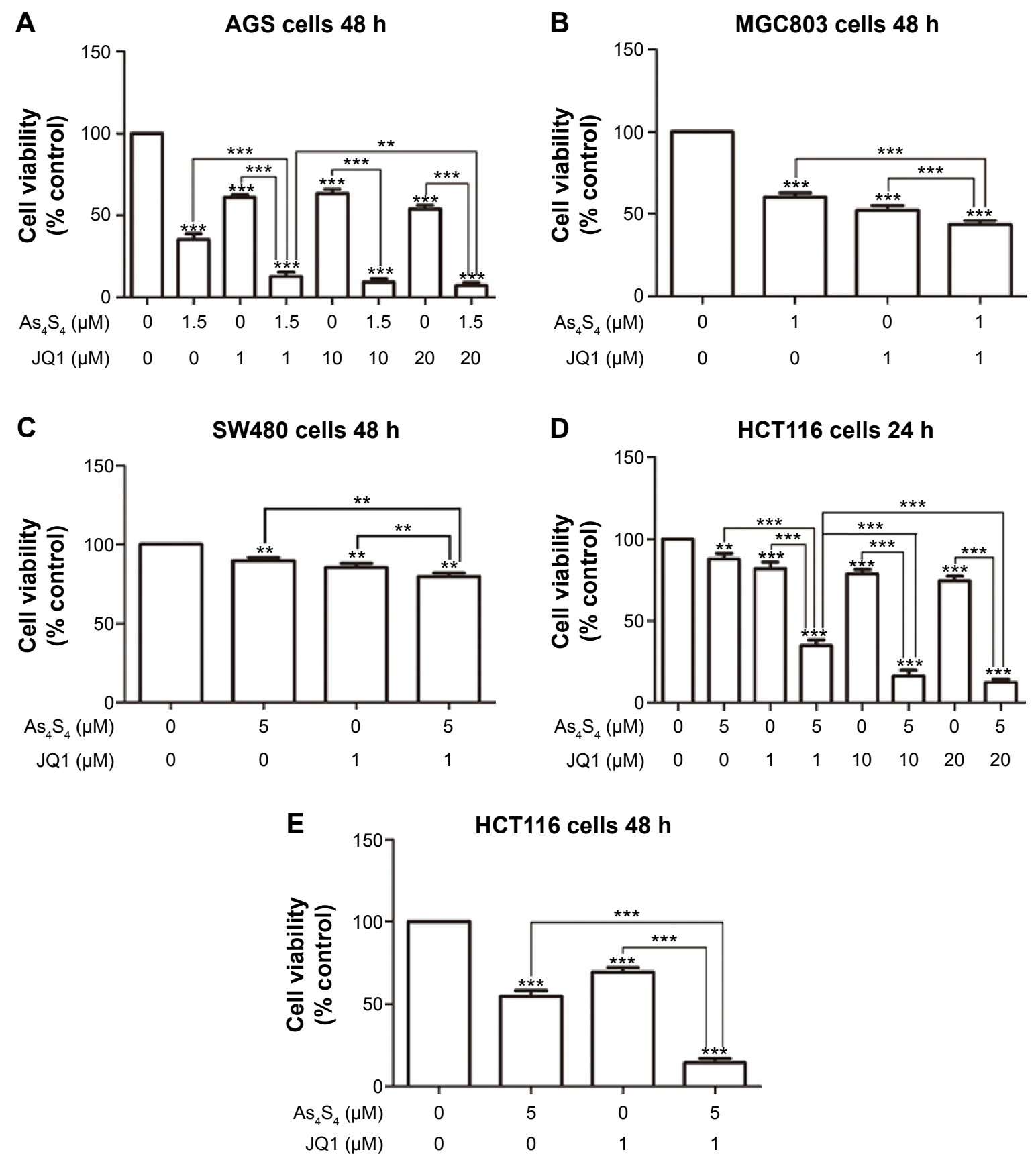

Figure I Cytotoxic effect of $\mathrm{As}_{4} \mathrm{~S}_{4}$ in combination with JQI on gastric and colon cancer cells.

Notes: (A) AGS cells were treated with $\mathrm{As}_{4} \mathrm{~S}_{4}$ I.5 $\mu \mathrm{M}$ alone or in combination with JQ I (I or I0 $\left.\mu \mathrm{M}\right)$ for 48 hours. (B) MGC803 cells were treated with As $\mathrm{S}_{4}$ I $\mu \mathrm{M}$ alone or in combination with JQI I $\mu$ M for 48 hours. (C) SW480 cells were treated with $A_{4} S_{4} 5 \mu M$ alone or in combination with JQ I I $\mu M$ for 48 hours. (D and E) HCTII 6 cells were treated with $\mathrm{As}_{4} \mathrm{~S}_{4} 5 \mu \mathrm{M}$ alone or in combination with JQI (I.0 or $\left.10 \mu \mathrm{M}\right)$ for 24 and 48 hours. Data represent the mean \pm standard deviation of three independent experiments and the relative cell viability was expressed as the percentage of untreated well. $* * P<0.01, * * * P<0.00$ I.

Abbreviations: $\mathrm{As}_{4} \mathrm{~S}_{4}$, arsenic sulfide; h, hours.

indicating that in MGC803 gastric cancer cells the combined inhibitory effect of $\mathrm{As}_{4} \mathrm{~S}_{4}$ and JQ1 is significantly superior to either agent alone.

We then tested this combination in colon cancer cell lines. In SW480 cells, either $\mathrm{As}_{4} \mathrm{~S}_{4}$ or JQ1 showed a modest growth inhibitory effect and when both agents were combined, a modest but significantly enhanced effect was observed (Figure 1C). However, in HCT116 cells, the combined cytotoxic effect was much more pronounced. As shown in Figure 1D, as single agent, $\mathrm{As}_{4} \mathrm{~S}_{4}$ at $5.0 \mu \mathrm{M}$ showed a modest $15 \%$ inhibition of cell growth after 24 hours of treatment and JQ1 showed a $20 \%$ inhibition at $1.0,10$ or $20 \mu \mathrm{M}$. 
When $\mathrm{As}_{4} \mathrm{~S}_{4}$ was combined with JQ1 in all three concentrations, a synergistic effect was observed and the synergy was more pronounced with 10 and $20 \mu \mathrm{M}$ of JQ1. We tested this combination in HCT116 cells for 48 hours and observed a similar result (Figure 1E). These data indicate that $\mathrm{As}_{4} \mathrm{~S}_{4}$ and JQ1 combination enhanced cell killing in both gastric and colon cancer cells, however, the combined effect appears to be more pronounced in the p53 wild type cells (AGS and HCT116) than in p53 mutant cells (MGC803 and SW480).

\section{$\mathrm{As}_{4} \mathrm{~S}_{4}$ enhanced the cytotoxic effect of cisplatin or irinotecan in gastric and colon cancer cells}

We selected two commonly used and important chemotherapy drugs cisplatin and irinotecan to test their combined effect with $\mathrm{As}_{4} \mathrm{~S}_{4}$. Both chemotherapy drugs exert distinct mechanism yet share broad activity against multiple malignancies including gastric and colon cancer. ${ }^{18,19}$ As shown in Figure $2 \mathrm{~A}$, cisplatin at $7.5 \mu \mathrm{M}$ caused approximately $40 \%$ inhibition of cell growth in AGS cells in 24 hours, when combined with $\mathrm{As}_{4} \mathrm{~S}_{4}$ at $1.5 \mu \mathrm{M}$, this cell killing effect was significantly enhanced to approximately $60 \%$. When tested with 48 hours of treatment, the combined effect was even more pronounced (Figure 2B). A similar synergistic effect was observed in MGC803 cells (Figure 2C and D). These data indicate that arsenic and cisplatin have synergistic cell killing effects and may be an active regimen for further studies.

We further tested this combination in SW480 and HCT116 cells. As shown in Figure 2E and F, both $\mathrm{As}_{4} \mathrm{~S}_{4}$ and cisplatin as single agent showed a modest inhibitory effect on SW480 cells and the combined effect was also modestly increased in the 48-hour experiment (Figure 2F). In $\mathrm{HCT} 116$ cells, $\mathrm{As}_{4} \mathrm{~S}_{4}$ and cisplatin as single agent showed a modest but more pronounced effect and their combination showed a synergistic effect in both 24- and 48-hour experiments (Figure $2 \mathrm{G}$ and $\mathrm{H}$ ). These results again implicated mutant p53 as possible cause of drug resistance.

We tested whether $\mathrm{As}_{4} \mathrm{~S}_{4}$ and another important chemotherapy agent irinotecan could have a synergistic cytotoxic killing effect. In our study, when AGS cells were treated with low concentration irinotecan $(50 \mu \mathrm{M})$ for 24 hours, there was approximately $40 \%$ reduction of cell growth, and when $\mathrm{As}_{4} \mathrm{~S}_{4}$ and irinotecan were combined, the inhibition of the cell growth was approximately $60 \%$. Similar but more pronounced results were obtained with the treatment of AGS cells for 48 hours (data not shown). These results indicate that $\mathrm{As}_{4} \mathrm{~S}_{4}$ has a broad synergistic cell killing effect with chemotherapy agents.

\section{$\mathrm{As}_{4} \mathrm{~S}_{4}$ enhanced the inhibitory effect of celecoxib in colon cancer cells}

We sought to test if $\mathrm{As}_{4} \mathrm{~S}_{4}$ could enhance the inhibitory effect of COX2 inhibitor celecoxib in gastric and colon cancer cells. Celecoxib has been shown in several pre-clinical studies to have activities in reducing polyps and cell growth and is being studied for chemoprevention in several clinical trials currently. ${ }^{25,26}$ As shown in Figure 3A, celecoxib showed modest inhibition of cell growth in MGC803 cells, but its effect was enhanced by $\mathrm{As}_{4} \mathrm{~S}_{4}$. We then tested its combination in SW480 and HCT116 colon cancer cells and found similar enhancement in cell growth inhibition (Figure 3B-D). Again, the combined effect appeared more modest in SW480 cells (Figure 3B) but much more pronounced in HCT116 cells especially in the 48-hour experiment (Figure 3D). These data indicate that arsenic can enhance the cell growth inhibitory effect of celecoxib and may share similar targets such as COX2.

\section{$\mathrm{As}_{4} \mathrm{~S}_{4}$ and JQI synergistically inhibit BRD4 and c-Myc and activate p53}

To understand the mechanism underlying the synergistic effect of $\mathrm{As}_{4} \mathrm{~S}_{4}$ and JQ1, we performed Western blot to investigate such combination on the expression of several key proteins targeted by these two agents. As shown in Figure $4 \mathrm{~A}$ and $\mathrm{B}, \mathrm{As}_{4} \mathrm{~S}_{4}$ and JQ1 both showed inhibition of BRD4 and c-Myc expression, however, when both agents were combined a synergistic inhibition of both BRD4 and c-Myc was observed. $\mathrm{As}_{4} \mathrm{~S}_{4}$ stimulated 553 expression while JQ1 showed only modest effect (Figure 4C and D). However, when both agents were combined, p53 expression was much more enhanced (Figure 4C and D). These data indicate that $\mathrm{As}_{4} \mathrm{~S}_{4}$ and JQ1 likely share similar molecular targets that lead to the inhibition of c-Myc expression and the stimulation of $\mathrm{p} 53$.

\section{$\mathrm{As}_{4} \mathrm{~S}_{4}$ with cisplatin and celecoxib inhibit COX2 expression and activate apoptosis pathways}

We found that $\mathrm{As}_{4} \mathrm{~S}_{4}$ alone pronouncedly inhibited expression of COX2 enzyme and cyclin D1 (Figure 5A and B). The inhibition of COX2 expression was enhanced by cisplatin and celecoxib (Figure 5C and D). We also found that $\mathrm{As}_{4} \mathrm{~S}_{4}$ and cisplatin or celecoxib synergistically inhibited expression of 
A
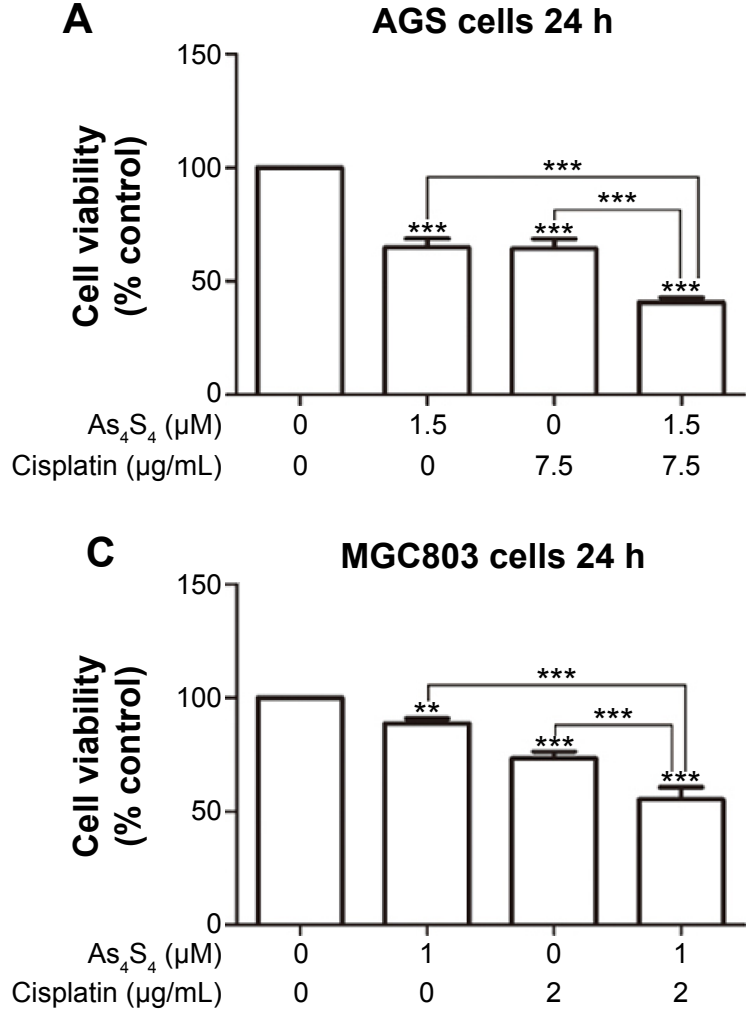

E

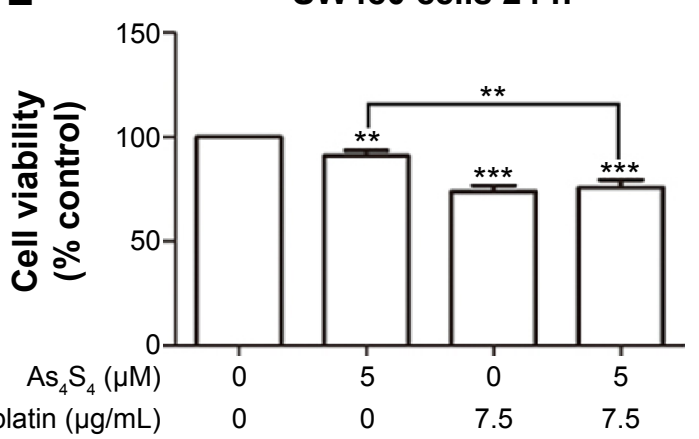

G

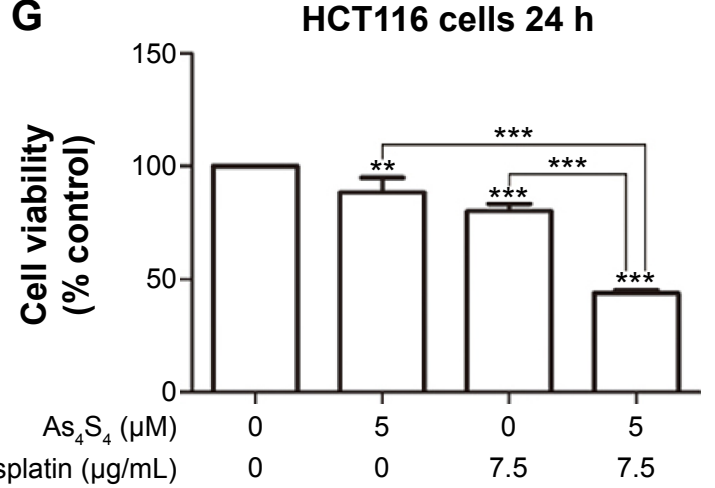

B

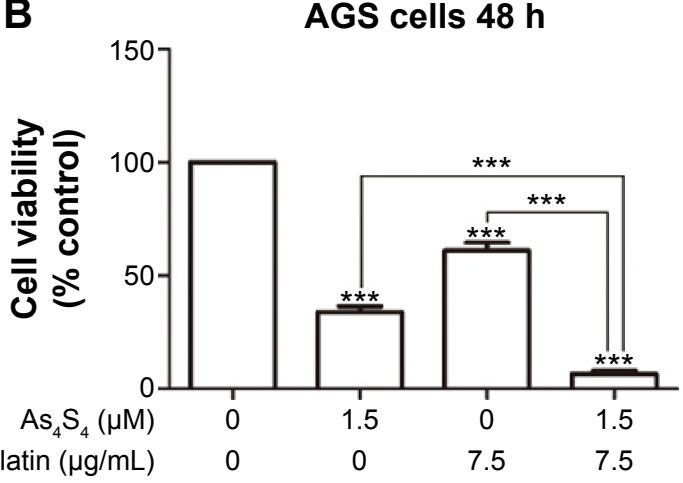

Cisplatin $(\mu \mathrm{g} / \mathrm{mL})$

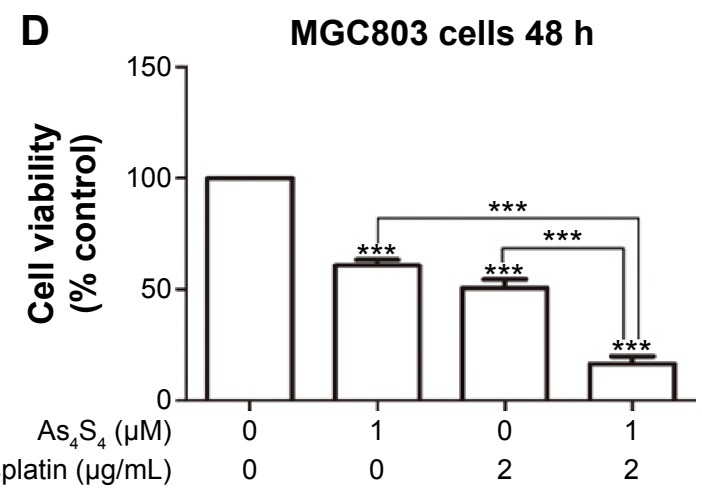

F

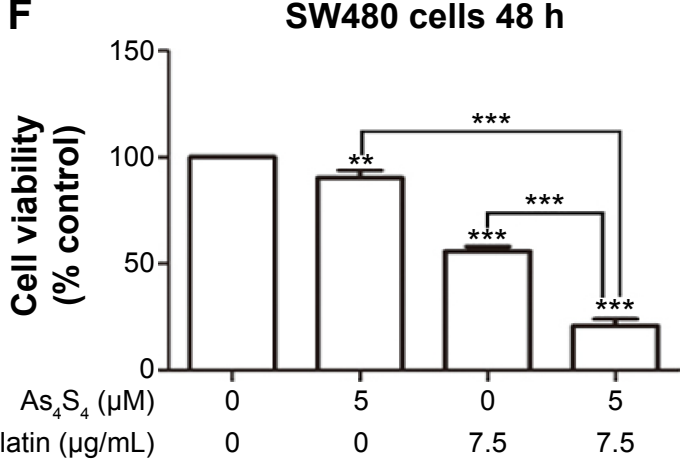

H

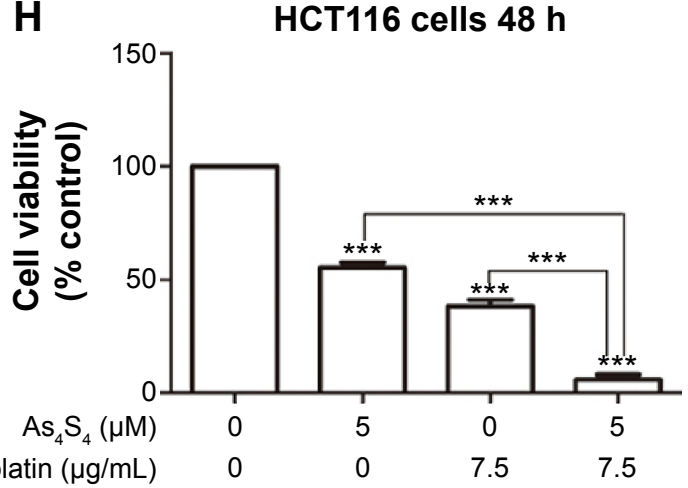

Figure 2 Cytotoxic effect of $\mathrm{As}_{4} \mathrm{~S}_{4}$ in combination with cisplatin on gastric and colon cancer cells.

Notes: (A and B) AGS cells were treated with $\mathrm{As}_{4} \mathrm{~S}_{4} \mathrm{I} .5 \mu \mathrm{M}$ alone or in combination with cisplatin $7.5 \mu \mathrm{g} / \mathrm{mL}$ for 24 and 48 hours. (C and D) MGC803 cells were treated with $\mathrm{As}_{4} \mathrm{~S}_{4} \mathrm{I} \mu \mathrm{M}$ alone or in combination with cisplatin $2 \mu \mathrm{g} / \mathrm{mL}$ for 24 and 48 hours. (E and $\mathbf{F}$ ) SW480 cells were treated with As $\mathrm{S}_{4} 5 \mu \mathrm{M}$ alone or in combination with cisplatin $7.5 \mu \mathrm{g} / \mathrm{mL}$ for 24 and 48 hours. ( $\mathbf{G}$ and $\mathbf{H}$ ) HCTI 6 cells were treated with As $\mathrm{S}_{4} 5 \mu \mathrm{M}$ alone or in combination with cisplatin $7.5 \mu \mathrm{g} / \mathrm{mL}$ for 24 and 48 hours. Data represent the mean \pm standard deviation of three independent experiments and the relative cell viability was expressed as the percentage of untreated well. The data represent one of three experiments with similar results. $* * P<0.01$, $* * * P<0.001$.

Abbreviations: $\mathrm{As}_{4} \mathrm{~S}_{4}$, arsenic sulfide; h, hours. 

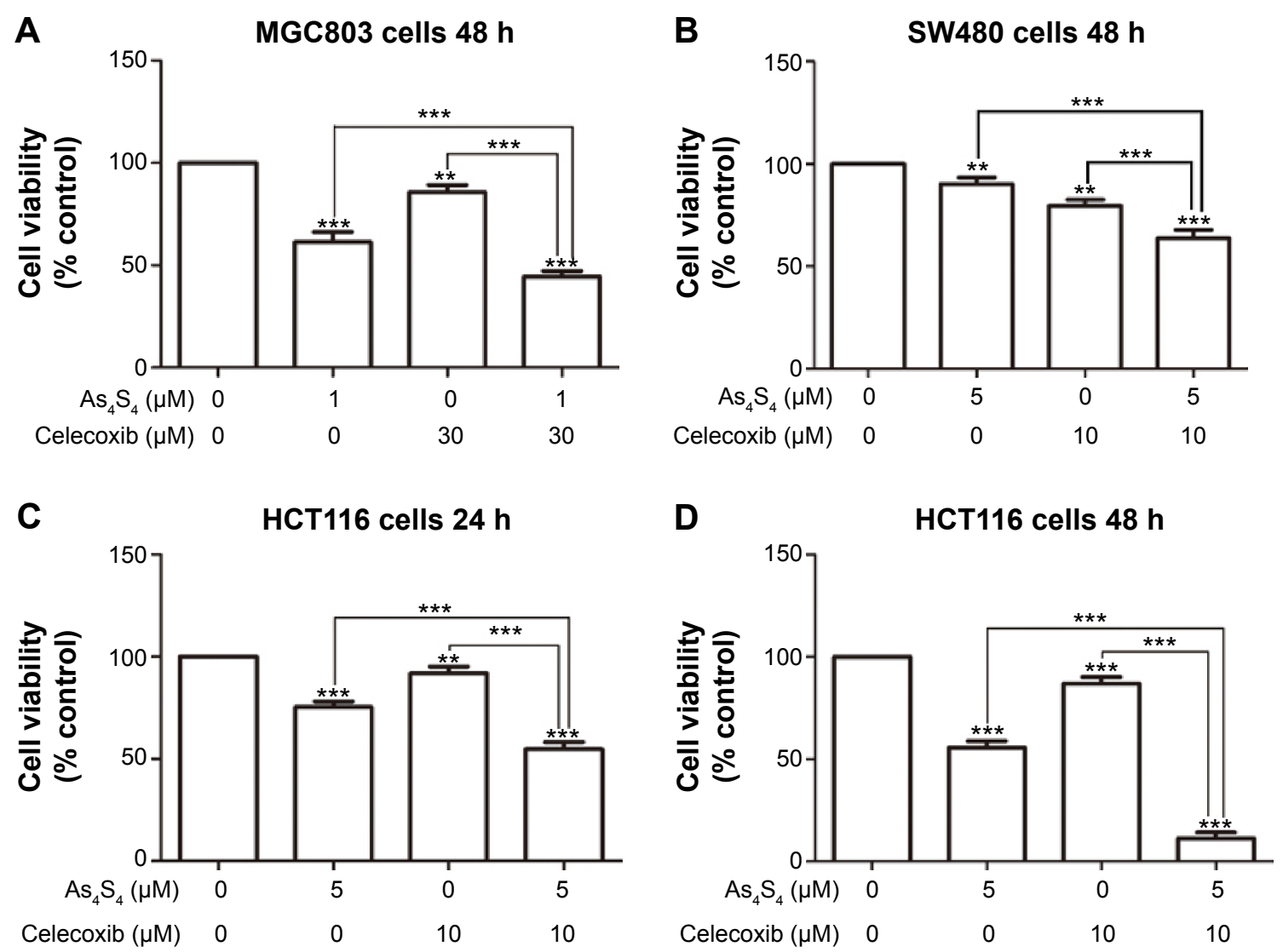

Figure 3 Cytotoxic effect of $\mathrm{As}_{4} \mathrm{~S}_{4}$ in combination with celecoxib on MGC803 and HCTII6 cells.

Notes: (A) MGC803 cells were treated with As $\mathrm{S}_{4} I \mu \mathrm{M}$ alone or in combination with celecoxib $30 \mu \mathrm{M}$ for 48 hours. (B) SW480 cells were treated with As $\mathrm{S}_{4} 5 \mu \mathrm{M}$ alone or in combination with celecoxib $10 \mu \mathrm{M}$ for 48 hours; (C and D) HCTII6 cells were treated with $\mathrm{As}_{4} \mathrm{~S}_{4} 5 \mu \mathrm{M}$ alone or in combination with celecoxib $10 \mu \mathrm{M}$ for 24 and 48 hours. Data represent the mean \pm standard deviation of three independent experiments and the relative cell viability was expressed as the percentage of untreated well. The data represent one of three experiments with the similar results. $* * P<0.0$ I, $* * * P<0.00$ I.

Abbreviations: $\mathrm{As}_{4} \mathrm{~S}_{4}$, arsenic sulfide; h, hours.
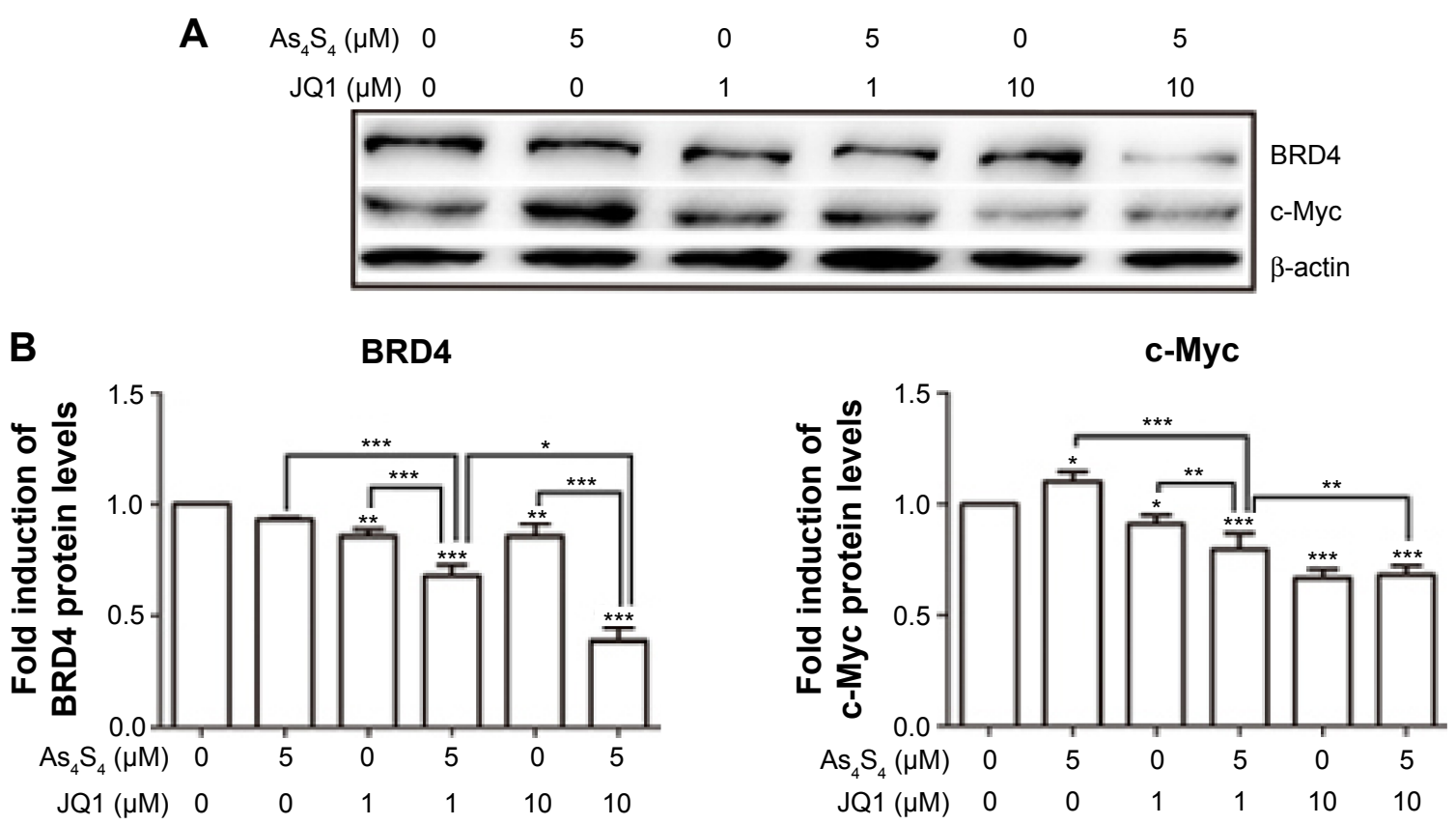

Figure 4 (Continued) 

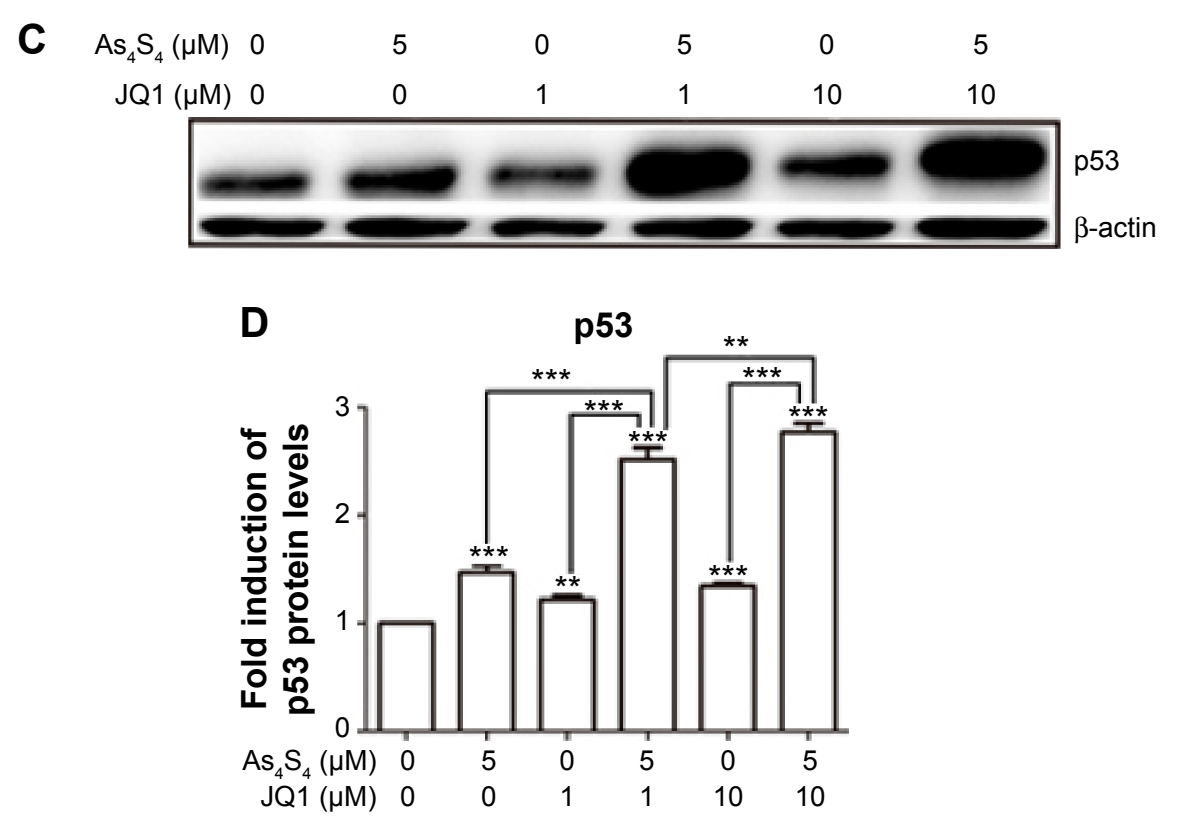

Figure $4 \mathrm{As}_{4} \mathrm{~S}_{4}$ and JQI synergistically inhibit BRD4, c-Myc and activate $\mathrm{p} 53$.

Notes: (A) Western blot analysis of BRD4 and c-Myc of HCTII6 treated with $5 \mu$ M As $S_{4}$, and/or I or I0 $\mu$ M JQI for 24 hours. (B) Relative quantitation and statistical analysis of protein expression in the Western blot in (A). (C) Western blot analysis of p53 of HCTII6 cells treated with $5 \mu$ M As $\mathrm{S}_{4}$, and/or I or $10 \mu \mathrm{M}$ JQI for 24 hours. $\beta$-actin was used as a loading control. (D) Relative quantitation and statistical analysis of protein expression in the Western blot in $(\mathbf{C})$. $* * P<0.0 \mathrm{I}$, $* * * P<0.00 \mathrm{I}$.

Abbreviation: $\mathrm{As}_{4} \mathrm{~S}_{4}$, arsenic sulfide.

A

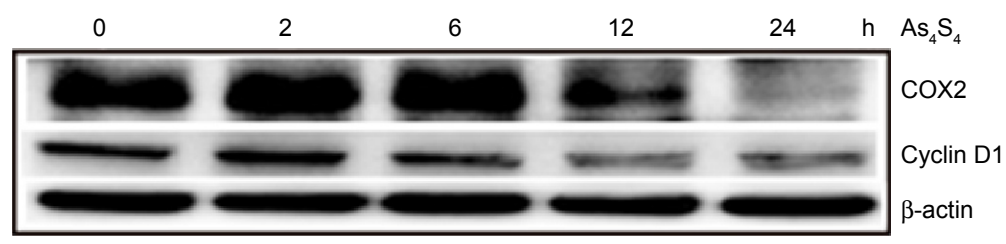

B

cox2

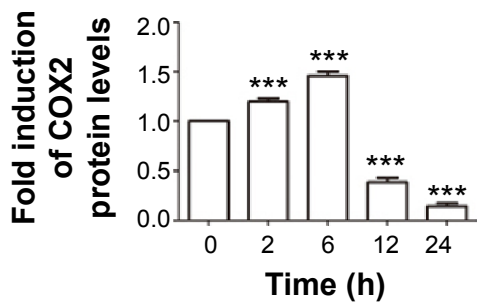

Cyclin D1

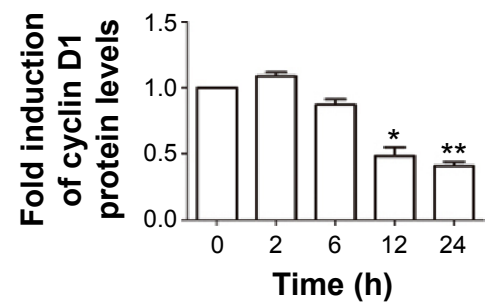

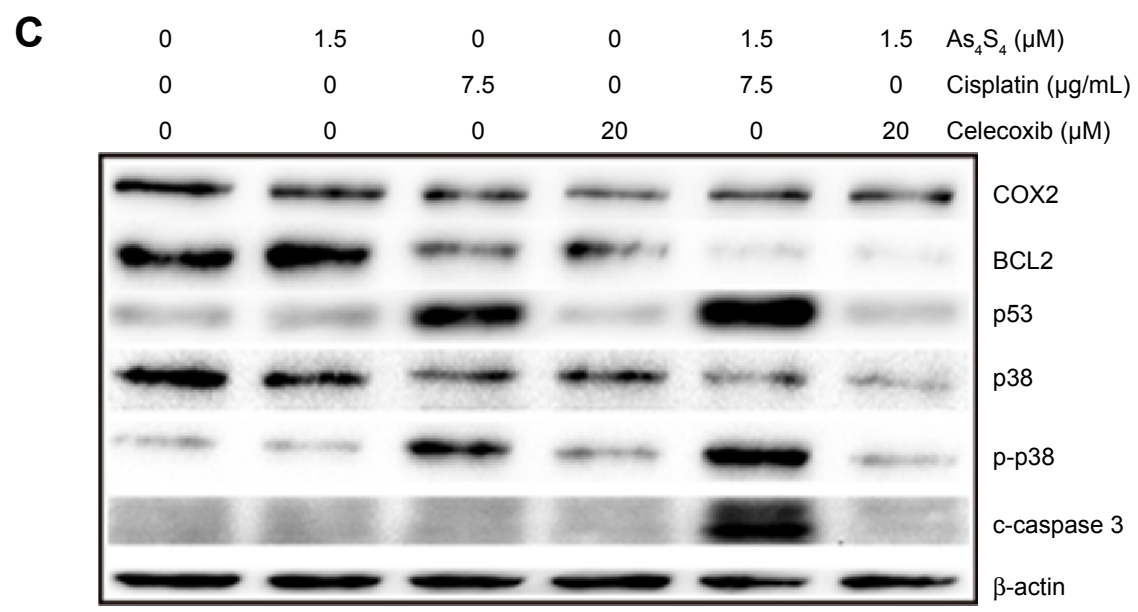

Figure 5 (Continued) 
D

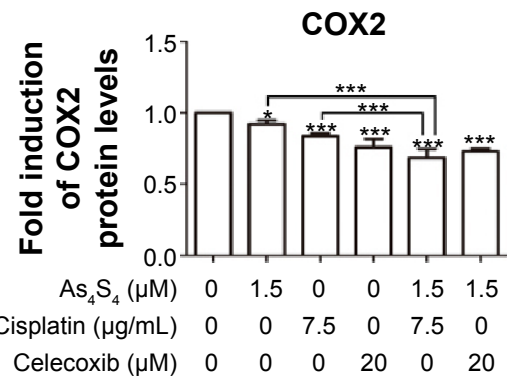

p53

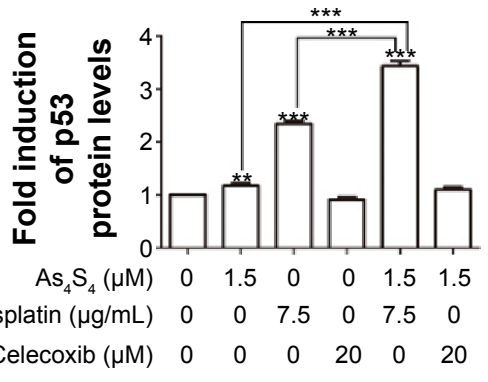

p-p38

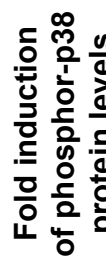

$\begin{array}{lllllll}\mathrm{As}_{4} \mathrm{~S}_{4}(\mu \mathrm{M}) & 0 & 1.5 & 0 & 0 & 1.5 & 1.5\end{array}$

Cisplatin $(\mu \mathrm{g} / \mathrm{mL}) \quad 0 \quad 007.5 \quad 0 \quad 7.5 \quad 0$

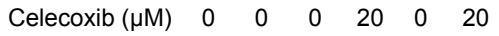

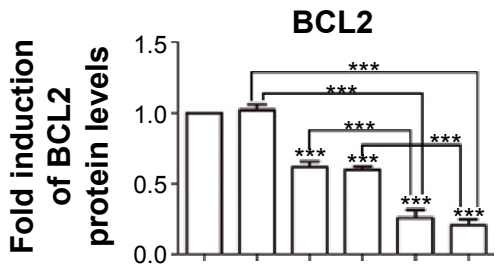

$\begin{array}{lllllll}\mathrm{As}_{4} \mathrm{~S}_{4}(\mu \mathrm{M}) & 0 & 1.5 & 0 & 0 & 1.5 & 1.5\end{array}$

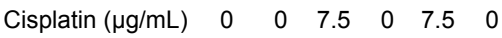

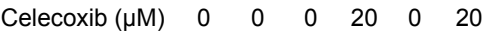

p38

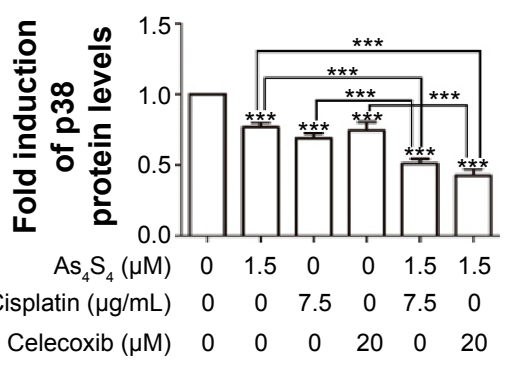

c-caspase 3

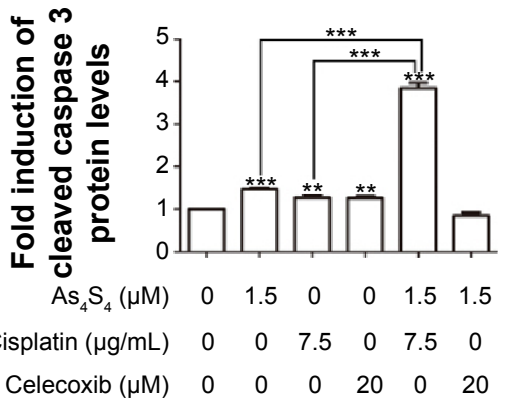

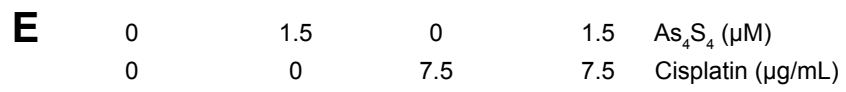

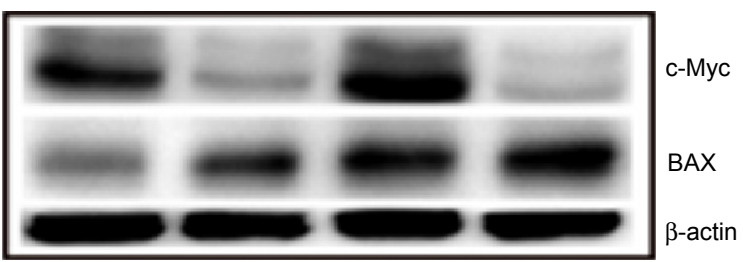

F

c-Myc

BAX
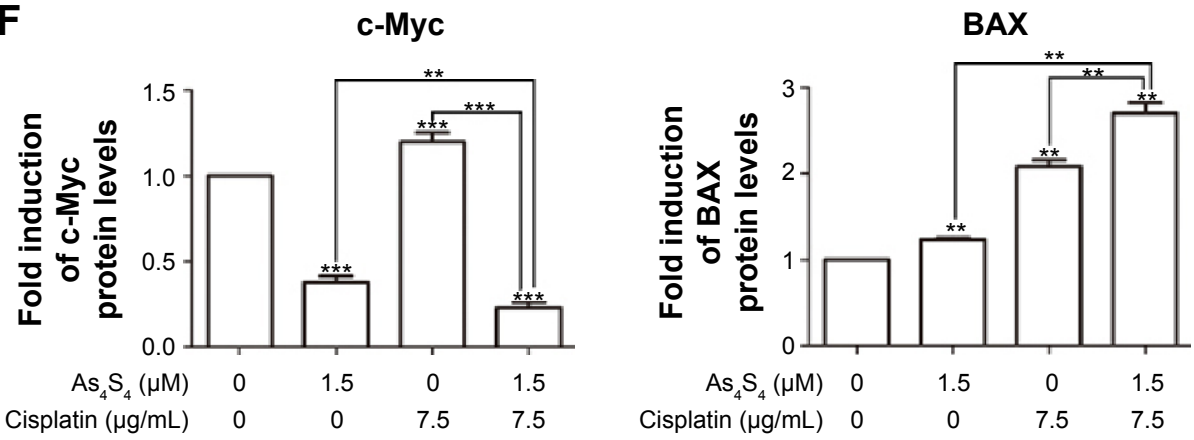

Figure $5 \mathrm{As}_{4} \mathrm{~S}_{4}$ combined with cisplatin or celecoxib alters the expression of several apoptosis-related proteins.

Notes: (A) Anti-COX2, anti-cyclin DI Western blot analysis of HCTII6 cells treated with $5 \mu \mathrm{M} \mathrm{As} \mathrm{S}_{4}$ for $0,2,6,12$, and 24 hours. (B) Relative quantitation and statistical analysis of protein expression in the Western blot in (A). (C) Western blot analysis of AGS cells treated with I.5 $\mu \mathrm{M} \mathrm{As} \mathrm{S}_{4}$, and/or $7.5 \mu \mathrm{g} / \mathrm{mL}$ cisplatin and/or $20 \mu \mathrm{M}$ celecoxib for 24 hours. Antibodies used in the blotting are indicated. (D) Relative quantitation and statistical analysis of protein expression in the Western blot in (C). (E) Western blot analysis of AGS cells treated with I.5 $\mu \mathrm{M} \mathrm{As}_{4} \mathrm{~S}_{4}$, and $/$ or $7.5 \mu \mathrm{g} / \mathrm{mL}$ cisplatin for 24 hours. Antibodies used in the blotting are indicated. $\beta$-actin was used as a loading control. (F) Relative quantitation and statistical analysis of protein expression in the Western blot in $(\mathbf{E}) . * P<0.05, * * P<0.0$ I, $* * * P<0.001$.

Abbreviations: $\mathrm{As}_{4} \mathrm{~S}_{4}$, arsenic sulfide; h, hours; p-p38, phosphor-p38; c-caspase 3, cleaved caspase 3. 
BCL2 (Figure 5C and D), while activating BAX expression (Figure 5E and F). We also found that $\mathrm{As}_{4} \mathrm{~S}_{4}$ impacts p38 pathway. $\mathrm{As}_{4} \mathrm{~S}_{4}$ alone inhibited $\mathrm{p} 38$ expression while increasing the level of phosphor-p38, and this effect was enhanced by cisplatin but not celecoxib (Figure $5 \mathrm{C}$ and D). $\mathrm{As}_{4} \mathrm{~S}_{4}$ and cisplatin in combination resulted in increased cleavage of caspase 3 (Figure $5 \mathrm{C}$ and D). These results indicate that $\mathrm{As}_{4} \mathrm{~S}_{4}$ and cisplatin and celecoxib affect multiple apoptosis pathways including p53, BCL/BAX, and p38 pathways.

\section{Discussion}

$\mathrm{As}_{2} \mathrm{O}_{3}$ is an important drug for treating APL. Its combination with ATRA has shown a synergistic effect in inducing APL cell differentiation and cell killing, leading to significantly better patient survival and cure rate. ${ }^{1-4,6-8}$ Here, we have shown that $\mathrm{As}_{4} \mathrm{~S}_{4}$, another important member of arsenic compounds with a similar cytotoxic effect to $\mathrm{As}_{2} \mathrm{O}_{3}$, can be combined with JQ1, a novel BRD4 inhibitor, or chemotherapy drugs cisplatin and irinotecan, or COX2 inhibitor celecoxib to enhance its cell killing effect. JQ1 alone showed an impressive growth inhibition effect in both gastric and colon cancer cell lines. $\mathrm{As}_{4} \mathrm{~S}_{4}$ combination with JQ1 showed an excellent synergistic effect in cell killing. Such combination is particularly interesting as JQ1 is a new agent that targets epigenetic modifier BRD4 and has been shown to be a potent inhibitor of multiple myeloma and acute myeloid leukemia cells. ${ }^{16,17}$ This combination may have excellent potential as a combination therapy strategy in the future in solid tumors and warrants further investigation in multiple myeloma and acute myeloid leukemia as well. Their synergistic inhibitory effects on c-Myc, a potent universal amplifier of gene transcription, indicate that the synergistic inhibition of cell growth is a sustainable effect. Their synergistic activation of p53 expression indicates that JQ1 may participate in modifying $\mathrm{p} 53$ pathway, in addition to inhibiting c-Myc. $\mathrm{As}_{4} \mathrm{~S}_{4}$ and JQ1 combination may be particularly effective in malignant hematologic disorders such as APL, acute myelogenous leukemia, and multiple myeloma and this investigation is currently underway in our laboratory.

$\mathrm{As}_{4} \mathrm{~S}_{4}$ also showed excellent activity when combined with chemotherapy drug cisplatin and irinotecan, two important drugs in gastric and colon cancer. $\mathrm{As}_{4} \mathrm{~S}_{4}$ showed an enhanced cell killing effect of cisplatin and irinotecan indicating its potential in clinical utility in these cancers. Though cisplatin and irinotecan have reasonable cytotoxic activity in gastric and colorectal cancer, as a single agent their efficacy is still limited. The combination regimens such as EOX (epirubicin, oxaliplatin, and capecitabine), ECF (epirubicin, cisplatin, and 5-fluorouracil infusion),
FOLFIRI (5-fluorouracil, irinotecan, and leucovorin), and FOLFIRINOX (5-fluorouracil, irinotecan, oxaliplatin and leucovorin) have much better activity and produce significantly higher response rate in gastric, colorectal, or pancreatic cancer. ${ }^{34-37}$ The combination of $\mathrm{As}_{4} \mathrm{~S}_{4}$ and chemotherapy agents may potentially provide better response activity for cancer of the gastrointestinal tract.

Celecoxib is a unique COX2 inhibitor that blocks the synthesis of inflammatory prostaglandins and therefore suppresses the growth stimulatory effect of these cytokines. ${ }^{20-22}$ Some studies found that celecoxib had a synergistic antitumor effect in combination with several other chemotherapeutic agents. ${ }^{38,39}$ Colon cancer is known to be associated with chronic inflammation and its development is much increased in patients with ulcerative colitis or Crohn's disease. ${ }^{40-42}$ $\mathrm{As}_{4} \mathrm{~S}_{4}$ showed inhibition of $\mathrm{COX} 2$ expression which was also enhanced by the addition of cisplatin and celecoxib (Figure 5A-D), indicating that they share similar targets and growth inhibition effect. $\mathrm{As}_{4} \mathrm{~S}_{4}$ and cisplatin or celecoxib showed activity in activating multiple apoptosis pathways including p53, BAX, and p38 (Figure 5C-F). These results indicate that arsenic has broad activity in inhibiting several growth-promoting signaling pathways while stimulating apoptosis to suppress cell growth and enhance cell killing. Though it is unlikely that arsenic and celecoxib combination would have clinical application in the future, their synergistic or enhanced effect provides an interesting mechanistic understanding of the molecular mechanisms of drug-drug interaction.

It is worth pointing out that the combination of $\mathrm{As}_{4} \mathrm{~S}_{4}$ and JQ1, cisplatin, irinotecan, and celecoxib showed a consistently less potent inhibitory effect in both MGC803 and SW480 cell lines that harbor a p53 mutant, indicating that p53 mutation likely confers drug resistance to these cell lines.

In conclusion, our results have shown that $\mathrm{As}_{4} \mathrm{~S}_{4}$ can be combined with JQ1, cisplatin, irinotecan, and celecoxib to inhibit cell growth and enhance cell killing in gastric and colon cancer cells and some of these novel combinations may have potential clinical applications in the future and warrant further studies including in vivo investigations. The $\mathrm{As}_{4} \mathrm{~S}_{4}$ and JQ1 combination is particularly interesting and we are currently investigating its role in malignant hematologic disorders.

\section{Acknowledgments}

This work was supported by the National Natural Science Foundation of China (81274142, 30300139), and the Natural Science Foundation of Science and Technology Commission of Shanghai Municipality (11ZR1423400) and the 
Key Project of Shanghai Municipal Education Commission (07zz43) to SC. MP was supported by Jiayan Foundation.

\section{Disclosure}

The authors have no conflicts of interest to disclose.

\section{References}

1. Shen ZX, Shi ZZ, Fang J, et al. All-trans retinoic acid/As2O3 combination yields a high quality remission and survival in newly diagnosed acute promyelocytic leukemia. Proc Natl Acad Sci USA. 2004;101(15):5328-5335.

2. Chen SJ, Zhou GB, Zhang XW, Mao JH, de Thé H, Chen Z. From an old remedy to a magic bullet: molecular mechanisms underlying the therapeutic effects of arsenic in fighting leukemia. Blood. 2011;117(24):6425-6437.

3. Wu T, Zhao J, Jian B, et al. Tetra-Arsenic Tetra-Sulfide Containing Triple-Agent Regimen as the First Line Therapy for Acute Promyelocytic Leukemia: Expeditiously Consecutive Complete Remission and Improved Disease-Free Survival. Blood. In: American Society of Hematology Annual Meeting; Atlanta, Georgia: December 8-11, 2007. Abstract 591.

4. Emadi A, Gore SD. Arsenic Trioxide - An Old Drug Rediscovered. Blood Rev. 2010;24(4-5):191-199.

5. Lu DP, Qiu JY, Jiang B, et al. Tetra-arsenic tetra-sulfide for the treatment of acute promyelocytic leukemia: a pilot report. Blood. 2002;99(9):3136-3143.

6. Zhang XW, Yan XJ, Zhou ZR, et al. Arsenic trioxide controls the fate of the PML-RARalpha oncoprotein by directly binding PML. Science. 2010;328(5975):240-243.

7. Chen S, Fang Y, Ma L, Liu S, Li X. Realgar-induced apoptosis and differentiation in all-trans retinoic acid (ATRA)-sensitive $\mathrm{NB}_{4}$ and ATRA-resistant MR $\mathrm{MR}_{2}$ cells. Int J Oncol. 2012;40(4):1089-1096.

8. Mao JH, Sun XY, Liu JX, et al. $\mathrm{As}_{4} \mathrm{~S}_{4}$ targets RING-type E3 ligase c-CBL to induce degradation of BCR-ABL in chronic myelogenous leukemia. Proc Natl Acad Sci U S A. 2010;107(50):21683-21688.

9. Chen S, Zheng L, Liu J, et al. Effects of Realgar (tetra-arsenic tetra-sulfide) on malignant tumor cells. J Clin Oncol. 2011;29:(suppl; abstr e13525).

10. Ding WP, Zhang L, Kim SK, et al. Arsenic sulfide as a potential anticancer drug. Mol Med Rep. 2015;11(2):968-974.

11. Zhang L, Tian W, Kim S, Ding W, Tong Y, Chen S. Arsenic sulfide, the main component of a traditional Chinese medicine, induces apoptosis of gastric cancer cells in vitro and in vivo. Drug Des Devel Ther. 2014;9:79-92.

12. Shi J, Vakoc CR. The mechanisms behind the therapeutic activity of BET bromodomain inhibition. Mol Cell. 2014;54(5):728-736.

13. Qi J. Bromodomain and extraterminal domain inhibitors (BETi) for cancer therapy: chemical modulation of chromatin structure. Cold Spring Harb Perspect Biol. 2014;6(12):a018663.

14. Roe JS, Mercan F, Rivera K, Pappin DJ, Vakoc CR. BET Bromodomain Inhibition Suppresses the Function of Hematopoietic Transcription Factors in Acute Myeloid Leukemia. Mol Cell. 2015;58(6):1028-1039.

15. Delmore JE, Issa GC, Lemieux ME, et al. BET bromodomain inhibition as a therapeutic strategy to target c-Myc. Cell. 2011;146(6):904-917.

16. Zuber J, Shi J, Wang E, et al. RNAi screen identifies Brd4 as a therapeutic target in acute myeloid leukaemia. Nature. 2011;478(7370): 524-528.

17. Lovén J, Hoke HA, Lin CY, et al. Selective inhibition of tumor oncogenes by disruption of super-enhancers. Cell. 2013;153(2):320-334.

18. Siddik ZH. Cisplatin: mode of cytotoxic action and molecular basis of resistance. Oncogene. 2003;22(47):7265-7279.

19. Garcia-Carbonero R, Supko JG. Current perspectives on the clinical experience, pharmacology, and continued development of the camptothecins. Clin Cancer Res. 2002;8(3):641-661.

20. Oshima M, Dinchuk JE, Kargman SL, et al. Suppression of intestinal polyposis in Apc delta716 knockout mice by inhibition of cyclooxygenase 2 (COX-2). Cell. 1996;87(5):803-809.
21. Lal G, Ash C, Hay K, et al. Suppression of intestinal polyps in Msh2deficient and non-Msh2-deficient multiple intestinal neoplasia mice by a specific cyclooxygenase- 2 inhibitor and by a dual cyclooxygenase-1/2 inhibitor. Cancer Res. 2001;61(16):6131-6136.

22. Thun MJ, Henley SJ, Patrono C. Nonsteroidal anti-inflammatory drugs as anticancer agents: mechanistic, pharmacologic, and clinical issues. J Natl Cancer Inst. 2002;94(4):252-266.

23. Reddy BS, Hirose Y, Lubet R, et al. Chemoprevention of colon cancer by specific cyclooxygenase- 2 inhibitor, celecoxib, administered during different stages of carcinogenesis. Cancer Res. 2000;60(2):293-297.

24. Koki AT, Masferrer JL. Celecoxib: a specific COX-2 inhibitor with anticancer properties. Cancer Control. 2002;9(2 Suppl):28-35.

25. Steinbach G, Lynch PM, Phillips RK, et al. The effect of celecoxib, a cyclooxygenase-2 inhibitor, in familial adenomatous polyposis. $N$ Engl J Med. 2000;342(26):1946-1952.

26. Bertagnolli MM, Eagle CJ, Zauber AG, et al. Celecoxib for the prevention of sporadic colorectal adenomas. N Engl J Med. 2006;355(9): 873-884.

27. Agrawal A, Fentiman IS. NSAIDs and breast cancer: a possible prevention and treatment strategy. Int J Clin Pract. 2008;62(3):444-449.

28. Printz C. Celecoxib may prevent lung cancer. Cancer. 2012;118(1):3.

29. Qiu H, Jackson AL, Kilgore JE, et al. JQ1 suppresses tumor growth through downregulating LDHA in ovarian cancer. Oncotarget. 2015;6(9):6915-6930.

30. Li Z, Wu C, Wu J, et al. Synergistic antitumor effects of combined deguelin and cisplatin treatment in gastric cancer cells. Oncol Lett. 2014;8(4):1603-1607.

31. Yuan TM, Liang RY, Chueh PJ, Chuang SM. Role of ribophorin II in the response to anticancer drugs in gastric cancer cell lines. Oncol Lett. 2015;9(4):1861-1868.

32. Kim J, Kim N, Park JH, et al. The Effect of Helicobacter pylori on Epidermal Growth Factor Receptor Induced Signal Transduction and the Preventive Effect of Celecoxib in Gastric Cancer Cells. Gut Liver. 2013;7(5):552-559.

33. Wang H, Ke F, Zheng J. Hedgehog-glioma-associated oncogene homolog-1 signaling in colon cancer cells and its role in the celecoxibmediated anti-cancer effect. Oncol Lett. 2014;8(5):2203-2208.

34. Cunningham D, Starling N, Rao S, et al. Capecitabine and oxaliplatin for advanced esophagogastric cancer. N Engl J Med. 2008;358(1):36-46.

35. Zaniboni A, Barni S, Labianca R, et al. Epirubicin, cisplatin, and continuous infusion 5-fluorouracil is an active and safe regimen for patients with advanced gastric cancer. An Italian Group for the Study of Digestive Tract Cancer (GISCAD) report. Cancer. 1995;76(10):1694-1699.

36. Guimbaud R, Louvet C, Ries P, et al. Prospective, randomized, multicenter, phase III study of fluorouracil, leucovorin, and irinotecan versus epirubicin, cisplatin, and capecitabine in advanced gastric adenocarcinoma: a French intergroup (Fédération Francophone de Cancérologie Digestive, Fédération Nationale des Centres de Lutte Contre le Cancer, and Groupe Coopérateur Multidisciplinaire en Oncologie) study. J Clin Oncol. 2014;32(31):3520-3526.

37. Conroy T, Desseigne F, Ychou M, et al. FOLFIRINOX versus gemcitabine for metastatic pancreatic cancer. $N$ Engl J Med. 2011;364(19): 1817-1825.

38. Milella M, Gelibter A, Di Cosimo S, et al. Pilot study of celecoxib and infusional 5-fluorouracil as second-line treatment for advanced pancreatic carcinoma. Cancer. 2004;101(1):133-138.

39. Altorki NK, Keresztes RS, Port JL, et al. Celecoxib, a selective cyclooxygenase- 2 inhibitor, enhances the response to preoperative paclitaxel and carboplatin in early-stage non-small-cell lung cancer. J Clin Oncol. 2003;21(14):2645-2650.

40. Eaden JA, Abrams KR, Mayberry JF. The risk of colorectal cancer in ulcerative colitis: a meta-analysis. Gut. 2001;48(4):526-535.

41. Munkholm P. Review article: the incidence and prevalence of colorectal cancer in inflammatory bowel disease. Aliment Pharmacol Ther. 2003;18 Suppl 2:1-5.

42. Zhiqin W, Palaniappan S, Raja Ali RA. Inflammatory Bowel Diseaserelated Colorectal Cancer in the Asia-Pacific Region: Past, Present, and Future. Intest Res. 2014;12(3):194-204. 


\section{Publish your work in this journal}

Drug Design, Development and Therapy is an international, peerreviewed open-access journal that spans the spectrum of drug design and development through to clinical applications. Clinical outcomes, patient safety, and programs for the development and effective, safe, and sustained use of medicines are a feature of the journal, which

has also been accepted for indexing on PubMed Central. The manuscript management system is completely online and includes a very quick and fair peer-review system, which is all easy to use. Visit http://www.dovepress.com/testimonials.php to read real quotes from published authors.

Submit your manuscript here: http://www.dovepress.com/drug-design-development-and-therapy-journal 